УДК 631.11:339.137.2

DOI: 10.15673/fie.v11i2.1396

\author{
Найда I.C. \\ кандидат економічних наук, асистент \\ кафредра менеджменту \\ E-mail: irochka.lobankina@gmail.com \\ ORCID ID: 0000-0002-9706-7724
}

\author{
Найда А.B. \\ кандидат економічних наук, доцент \\ кафедра обліку і оподаткування \\ E-mail: andrew.od2017@gmail.com \\ ORCID ID: 0000-0002-6371-1382
}

Галицький О.М.

доктор економічних наук, доцент кафедра економічної теорії і економіки підприємства

Одеський державний аграрний університет

вул. Пантелеймонівська, 13, м. Одеса, Україна, 65012

E-mail: oleksandrgalickij9@gmail.com

ORCID ID: 0000-0001-9549-7627

\title{
СУЧАСНІ ІНСТРУМЕНТИ ОЦІНКИ КОНКУРЕНТОСПРОМОЖНОСТІ СІЛЬСЬКОГОСПОДАРСЬКОГО ПІДПРИЄМСТВА
}

У статті узагальнено методичні підходи щодо оцінки конкурентоспроможності сільськогосподарських підприємств. Обґрунтовано необхідність використання різних методик для оцінювання рівня конкурентоспроможності підприємств, що забезпечить отримання ґрунтовних результатів, дасть можливість визначити стратегічну позицію кожного підприємства, що є важливим для розробки стратегічних напрямів. Здійснено оцінку конкурентоспроможності сільськогосподарських підприємств з використанням сучасного інструментарію (профіль конкурентоспроможності, багатокутник конкурентоспроможності, бенчмаркінг). Встановлено, що основними конкурентними перевагами для сільськогосподарських підприємств $є$ низька собівартість, що супроводжується відносною високою ресурсовіддачею та максимально повним використанням конкурентного потенціалу; вигідні реалізаційні ціни; висока ефективність діяльності. Розроблено напрями підвищення конкурентоспроможності сільськогосподарських підприємств.

Ключові слова: сільськогосподарські підприємства, конкурентоспроможність, оцінка конкурентоспроможності, конкурентні переваги, конкурентний профіль, бенчмаркінг.

This work is licensed under a Creative Commons Attribution 4.0 International License http://creativecommons.org/licenses/by/4.0/

Постановка проблеми та її зв'язок 3 важливими науковими та практичними завданнями. Активізація євроінтеграційних процесів та поступова лібералізація зовнішньої торгівлі створює перспективи для виходу вітчизняних сільськогосподарських підприємств на світові ринки та водночас формує передумови доступу іноземних товаровиробників на внутрішні ринки. Утримання стійких конкурентних позицій вітчизняних підприємств потребує забезпечення відповідності сільськогосподарської продукції міжнародним стандартам якості та безпеки, обгрунтування системи стратегічних напрямів розвитку 3 позицій інноваційності, найменшої ризиковості та максимальної ефективності.

Відтак, актуальності набуває питання забезпечення високого рівня конкурентоспроможності підприємств України та відповідність їх виробленої продукції європейським вимогам ринку. В свою чергу, це потребує здійснення оцінки конкурентоспроможності підприємств, що передбачає, насамперед, визначення системи показників та достовірних методів їх оцінювання.
Аналіз останніх публікацій по проблемі. Дослідженню проблем конкурентоспроможності підприємств та оцінки іiі рівня присвячені наукові праці зарубіжних вчених-економістів, зокрема Г. Азоєва [1], М. Портера [2], А. Томпсона [3], Р. Фатхудінова [4], Й. Шумпетера [5] та інших. Серед вітчизняних вчених, які займаються дослідженням питань формування високого рівня конкурентоспроможності сільськогосподарських підприємств, вагомий внесок зробили В.Я. Амбросов [6], Г.М. Запша [7], В.К. Збарський [8], М.Й. Малік [9], О.А. Нужна [9], М.П. Сахацький [10], О.В. Ульянченко [11], О.Г. Янковий [12], І.Б. Яців [13] та інші. Однак, незважаючи на значну кількість публікацій, визначення оптимального інструментарію оцінки конкурентоспроможності сільськогосподарських підприємств, який б враховував специфіку та особливості їх діяльності, потребує подальшого наукового дослідження.

Формулювання цілей дослідження. Обгрунтування сучасних інструментів оцінки конкурентоспроможності сільськогосподарських 
підприємств та розробка пропозицій щодо зміцнення їх ринкових позицій.

Виклад основних результатів та їх обгрунтування. В умовах ринкової економіки конкурентоспроможність сільськогосподарських підприємств є важливою характеристикою діяльності, виступаючи основою ефективного розвитку аграрної галузі України як на внутрішніх, так і зовнішніх ринках. Так, з позиції маркетингового та ресурсного підходів конкурентоспроможність підприємства розглядається як його спроможність зберігати або розширювати конкурентні позиції на цільовому ринку за рахунок ефективного використання природних, фінансових, матеріальних, кадрових й інформаційних ресурсів [14, с. 9]. Відповідно для успішної діяльності підприємства необхідно систематично здійснювати оцінку його конкурентоспроможності, що дозволить визначити сильні та слабкі сторони підприємства, виявити його можливості та загрози, і в результаті удосконалити його стратегію функціонування.

Оцінка конкурентоспроможності підприємства - це визначення комплексу показників його виробничо-господарської діяльності, що визначають успіх підприємства на ринку, по відношенню до системи показників конкурентів.

Результати наукових досліджень свідчать про відсутність єдиного підходу щодо формування системи показників оцінки рівня конкурентоспроможності підприємства. Так, В.М. Трегобчук та Б.Й. Пасхавер для оцінки конкурентоспроможності аграрних підприємств пропонують використовувати такі показники, як рівень рентабельності виробництва та норму прибутку, продуктивність праці, ціну та якість продукції, товарність виробництва, його ліквідність та кредитоспроможність. Крім того, важливим $\epsilon$ аналіз ефективності використання земельних, трудових та матеріальних ресурсів [15, с. 51].

Оскільки у сільському господарстві земля $є$ основним ресурсом, показниками визначення рівня конкурентоспроможності виробництва, на думку I.B. Гуторова, є обсяг валової продукції та прибутку 3 розрахунку на 1 га сільськогосподарських угідь, на одного середньорічного працівника, на 1 грн. основних виробничих фондів, виробництво валової продукції на 1 грн. виробничих витрат, рентабельність виробництва [11, с. 56].

На думку В.Я. Амбросова та Т.Г. Маренич, при дослідженні конкурентоспроможності аграрного підприємства слід використовувати показники обсягу продажу продукції у вартісному вираженні та прибуток. Додатковими показниками можуть виступати порівняльний рівень собівартості продукції та ціна іiі реалізації $[6$, с. 26].

М.Й. Малік та О.А. Нужна вважать, що при оцінці конкурентоспроможності аграрних підприємств доцільно використовувати метод, що базується на теорії ефективної конкуренції. Згідно $з$ ним виділяється три групи показників: показники ефективності виробничої діяльності, показники фінансового стану підприємства та показники ділової активності. В результаті інтегральний показник конкурентоспроможності визначається методом середньозваженої арифметичної 3 врахуванням коефіцієнтів вагомості кожного групового показника. Проте автори зазначають, що найбільш простішим методом, що не містить великої кількості розрахунків, є бенчмаркінг [9, с. 51].

Парсяк В., Дибач I. зазначають, що конкурентоспроможність визначається результатами, отриманими у виробництві, маркетингу та менеджменті. Відповідно до цього пропонують виділити три найважливіших показники: собівартість виробленої продукції (щодо виробництва), обсяг збуту продукції (щодо маркетингу), прибуток (щодо менеджменту). Оцінка та аналіз отриманих значень у результаті діяльності підприємства дає змогу визначити резерви підвищення конкурентоспроможності підприємства [16, с. 59].

В науковій літературі за формою вираження результату оцінки конкурентоспроможності підприємства виділяють індексні, матричні та графічні методи (рис. 1).

Основною перевагою матричних та графічних методів оцінки конкурентоспроможності підприємства $€$ наочність та простота інтерпретації результатів. Проте вони орієнтовані на якісну оцінку конкурентоспроможності та мають високий ступінь суб'єктивізму. Тоді як індексні методи передбачають порівняння факторів конкурентоспроможності та надають узагальнену кількісну оцінку рівня конкурентоспроможності, однак має місце складність збору даних для проведення аналізу. Тому, при оцінці конкурентоспроможності підприємств вітчизняні науковці вважають доцільним використання комплексних методів, які передбачають розрахунок показників, що характеризують виробничий, фінансово-економічний, техніко-технологічний, кадровий, інноваційний, маркетинговий та екологічний потенціали діяльності підприємства.

3 позицій універсальності для оцінки рівня конкурентоспроможності сільськогосподарських підприємств практичний інтерес становлять такі інструменти, як побудова профілю конкурентоспроможності, багатокутник конкурентоспроможності, збалансована система показників, бенчмаркінг.

Так, побудова профілю конкурентоспроможності підприємства дозволяє визначити місце підприємства у ринковому середовищі. Визначено, що основними конкурентами на ринку сільськогосподарської продукції Ширяївського району Одеської області є ТОВ «Батьківщина», ТОВ «Агрофірма Мар'янівська», ТОВ «Агрофірма «Прогрес-Плюс», СТОВ «Ольга». Для аналізу обрано саме ці підприємства, оскільки вони мають спільне географічне розташування, відповідно мають подібні природно-кліматичні умови, організаційно-правову форму та спеціалізуються на виробництві зернових та технічних культур. 


\section{I. ІНДЕКСНІ МЕТОДИ}

1. Метод, що грунтується на визначенні конкурентоспроможності продукції

2. Метод, в основу якого покладено теорію ефективної конкуренції

3. Метод, оснований на теорії конкурентних переваг

4. Метод інтегральної оцінки

5. Метод бенчмаркінгу

6. Індекс Херфіндаля-Хіршмана

7. Індекс Розенблюта

\section{II. МАТРИЧНІ МЕТОДИ}

1. Матриця БКГ

2. Матриця I. Ансофа

3. Матриця конкурентних стратегій М. Портера

4 Матриця GE/McKinsey

5. Матриця А. Томпсона і Р. Стрікленда

6. Матриця Shell/DPM

7. SWOT-аналіз

8. SРАCЕ-аналіз

9. STEР-аналіз

10. STEEPV-аналіз

\section{III. ГРАФІЧНІ МЕТОДИ}

1. Багатокутник конкурентоспроможності

2. Радар конкурентоспроможності

3. Метод «профілів»

4. Карта стратегічних груп

Рис. 1. Класифікація методів оцінки конкурентоспроможності підприємства за формою вираження результату*

*узагальнено авторами на основі $[8,9,11]$

Зокрема, визначено абсолютні та відносні господарських підприємств Ширяївського району показники конкурентоспроможності сільсько- Одеської області (табл. 1).

Таблиця 1

Показники конкурентоспроможності сільськогосподарських підприємств Ширяӥвського району

Одеської області *

\begin{tabular}{|c|c|c|c|c|c|c|c|c|c|}
\hline \multirow{2}{*}{$\begin{array}{l}\text { № } \\
\text { ח/п }\end{array}$} & \multirow[t]{2}{*}{ Показники } & \multicolumn{2}{|c|}{$\begin{array}{c}\text { TOB } \\
\text { "Батьківщина" }\end{array}$} & \multicolumn{2}{|c|}{$\begin{array}{c}\text { TOB "Агрофірма } \\
\text { Мар'янівська» }\end{array}$} & \multicolumn{2}{|c|}{$\begin{array}{l}\text { ТОВ «Агрофірма } \\
\text { «Прогрес-Плюс» }\end{array}$} & \multicolumn{2}{|c|}{ СТОВ «Ольга» } \\
\hline & & значення & бал & значення & бал & значення & бал & значення & бал \\
\hline \multicolumn{10}{|c|}{ Абсолютні показники } \\
\hline 1. & Площа с.-г. угідь, га & 1910 & 2 & 2852 & 4 & 2820 & 4 & 2408 & 4 \\
\hline 2. & $\begin{array}{l}\text { Середньорічна } \\
\text { чисельність працівників, } \\
\text { зайнятих в } \\
\text { сільськогосподарському } \\
\text { виробництві, осіб }\end{array}$ & 23 & 1 & 64 & 6 & 24 & 1 & 15 & 1 \\
\hline 3. & $\begin{array}{l}\text { Валова продукція } \\
\text { сільського господарства } \\
\text { в постійних цінах } 2010 \\
\text { року, тис. грн. }\end{array}$ & 11477,6 & 7 & 12109,5 & 8 & 15078,0 & 9 & 7234,5 & 4 \\
\hline 4. & Чистий прибуток, тис. грн & 9224 & 9 & 7254 & 7 & 12287 & 10 & 1103 & 1 \\
\hline
\end{tabular}


Продовження табл.1

\begin{tabular}{|c|c|c|c|c|c|c|c|c|c|}
\hline \multirow{2}{*}{$\begin{array}{c}\text { № } \\
\Pi / \Pi\end{array}$} & \multirow[t]{2}{*}{ Показники } & \multicolumn{2}{|c|}{$\begin{array}{c}\text { TОВ } \\
\text { "Батьківщина" }\end{array}$} & \multicolumn{2}{|c|}{$\begin{array}{l}\text { ТОВ "Агрофірма } \\
\text { Мар'янівська» }\end{array}$} & \multicolumn{2}{|c|}{$\begin{array}{l}\text { ТОВ «Агрофірма } \\
\text { «рогрес-Плюс» }\end{array}$} & \multicolumn{2}{|c|}{ СТОВ «Ольга» } \\
\hline & & значення & бал & значення & бал & значення & бал & значення & бал \\
\hline \multicolumn{10}{|c|}{ Відносні показники } \\
\hline 5. & $\begin{array}{l}\text { Вироблено валової } \\
\text { продукції в розрахунку } \\
\text { на } 1 \text { га с.-г. угідь, грн. }\end{array}$ & 6009,2 & 4 & 4246,0 & 2 & 5346,8 & 3 & 3004,4 & 2 \\
\hline 6. & $\begin{array}{l}\text { Вироблено валової } \\
\text { продукції в розрахунку на } \\
1 \text { працівника, тис. грн. }\end{array}$ & 499,0 & 9 & 189,2 & 3 & 628,3 & 10 & 482,3 & 9 \\
\hline 7. & $\begin{array}{l}\text { Одержано прибутку в } \\
\text { розрахунку на } 1 \text { га с.-г. } \\
\text { угідь, грн. }\end{array}$ & 4829,3 & 2 & 2543,5 & 2 & 4357,1 & 2 & 458,1 & 1 \\
\hline 8. & $\begin{array}{l}\text { Одержано прибутку в } \\
\text { розрахунку на } 1 \\
\text { працівника, тис. грн. }\end{array}$ & 401,0 & 5 & 113,3 & 2 & 512,0 & 6 & 73,5 & 1 \\
\hline 9. & $\begin{array}{l}\text { Рівень рентабельності } \\
\text { діяльності підприємства, } \\
\%\end{array}$ & 50,2 & 5 & 22,6 & 1 & 55,3 & 5 & 35,3 & 3 \\
\hline
\end{tabular}

* сформовано авторами на основі даних фінансових звітів підприємств

Для узагальнення отриманих результатів побудовано профіль конкурентоспроможності основних сільськогосподарських підприємств Ширяївського

району Одеської області з використанням експертних оцінок за десятибальною шкалою (рис.2).

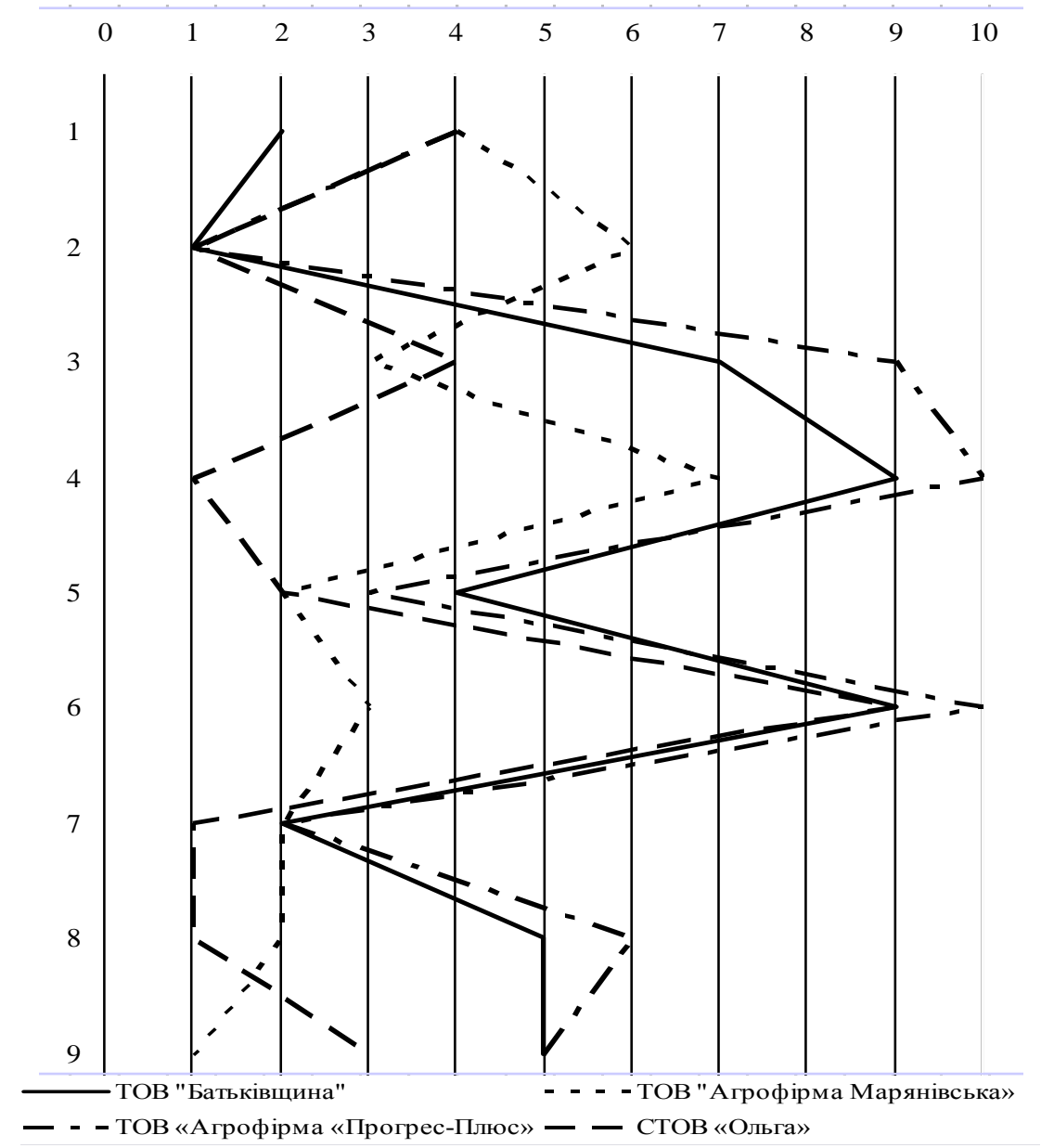

Рис. 2. Профіль конкурентоспроможності основних сільськогосподарських підприсмств Ширяївського району Одеської області за 2018 р.*

* побудовано авторами на основі даних табл. 1 
Дані рис. 2 дозволяють більш повно описати та наочно спостерігати конкурентні переваги та недоліки кожного підприємства. Так, за чисельністю працівників ТОВ «Агрофірма «Прогрес-Плюс», СТОВ «Ольга» та ТОВ «Батьківщина» відносяться до малих підприємств, а ТОВ «Агрофірма Мар'янівська» до середніх.

Характеризуючи виробництво валової продукції, спостерігаємо, що найвищого значення цей показник досягнув у ТОВ «Агрофірма «ПрогресПлюс» та ТОВ «Агрофірма Мар'янівська», що зумовлено значними розмірами сільськогосподарських угідь та використанням прогресивних технологій у їх виробничо-господарській діяльності. Крім того, за рівнем продуктивності праці та розміром прибутку на 1 працівника явним лідером є ТОВ «Агрофірма «Прогрес-Плюс». Безперечно, це є позитивним явищем, що впливає на ефективність роботи всього підприємства. Продуктивність ТОВ «Батьківщина» $\epsilon$ нижчою за значення основного конкурента. Про ефективність використання сільськогосподарських угідь свідчать обсяги вартості валової продукції в розрахунку на 1 га сільськогосподарських угідь. Так, найбільш ефективне використання земельного фонду спостерігається ТОВ «Батьківщина» та ТОВ «Агрофірма «Прогрес-Плюс».

3 наведених вище даних видно, що явними лідерами на ринку є ТОВ «Агрофірма «Прогрес-
Плюс» та ТОВ «Батьківщина». Кожне 3 цих підприємств за окремими показниками перевершує одне одного. ТОВ «Батьківщина» $\epsilon$ малим підприємством, саме тому для нього відкриті перспективи росту та розвитку, в його запасі ще $\epsilon$ невикористані можливості.

Сучасним інструментом, який наочно демонструє рівень конкурентоспроможності сільськогосподарських підприємств, є графічний метод, зокрема побудова багатокутника конкурентоспроможності. Його сутність полягає в тому, що підприємству, яке має найбільшу конкурентоспроможність, буде відповідати багатокутник з максимальною площею.

Використовуючи графічний метод оцінки конкурентоспроможності провідних сільськогосподарських підприємств Ширяївського району, визначено, що лідируючі позиції на ринку займає ТОВ «Агрофірма «Прогрес-Плюс» (рис. 3). 3 метою зміцнення своїх позицій на внутрішньому ринку сільськогосподарським підприємствам доцільно приділяти увагу таким складовим конкурентоспроможності, як рівню якості виготовленої продукції та середнім цінам на іiі реалізацію, вдосконаленню організації інноваційної діяльності, розвитку логістики та формуванню ефективних стратегій маркетингу.

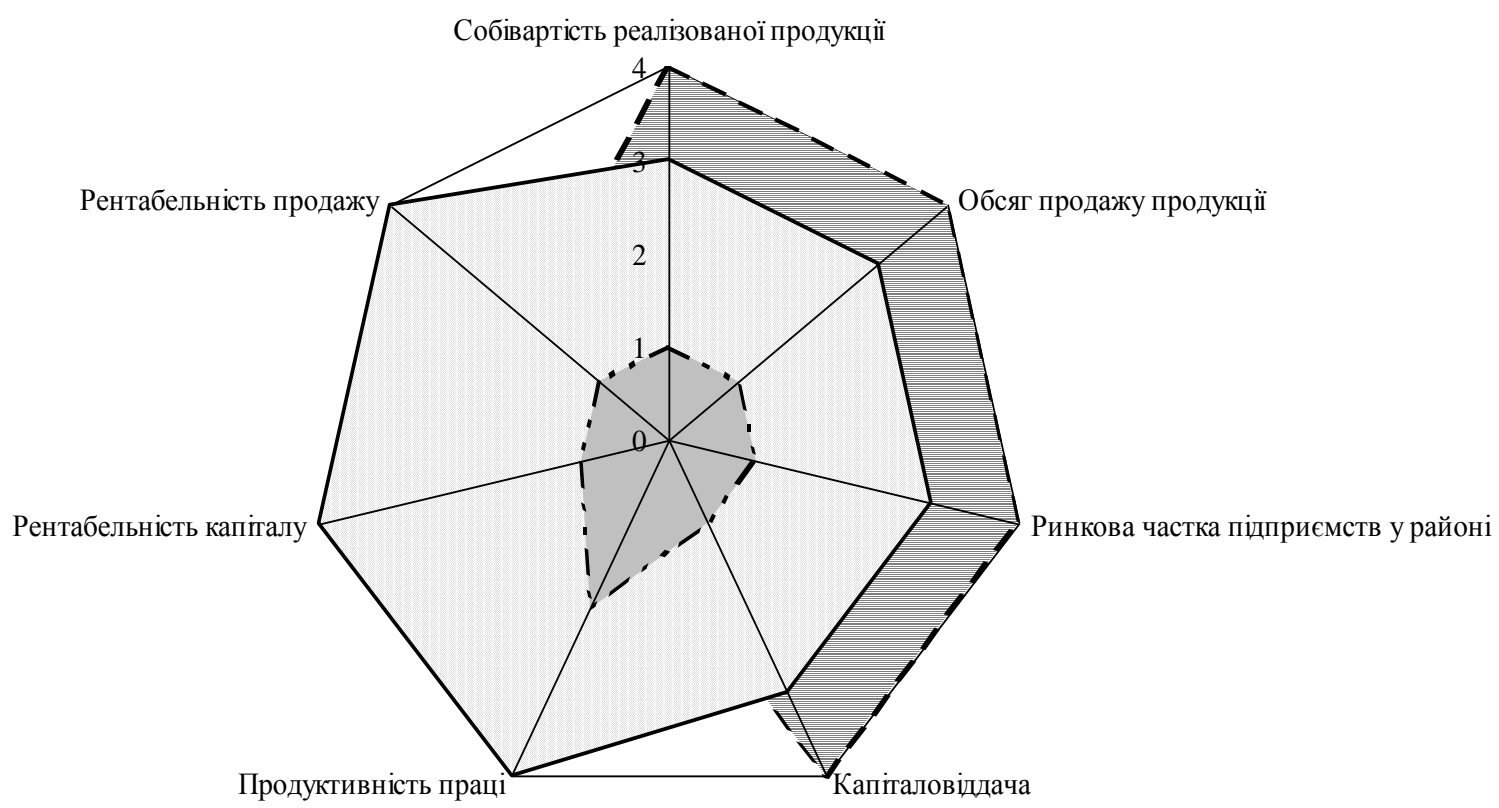

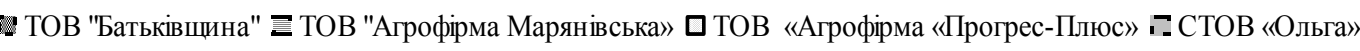

Рис. 3. Багатокутник конкурентоспроможності сільськогосподарських підприємств Ширяївського району*

* побудовано авторами на основі даних фінансових звітів підприємств 
Ще одним ефективним підходом щодо визначення конкурентоспроможності підприємства $€$ метод бенчмаркінгу. Вважаємо, що даний метод особливо доцільний в ситуації, коли необхідно переглянути внутрішню ефективність виробничогосподарської діяльності підприємства та визначити нові пріоритети розвитку. Зіставлення показників ефективності дає можливість визначити сильні та слабкі сторони діяльності підприємства порівняно 3 конкурентами і лідерами галузі, знайти незаповнені ринкові ніші. Порівнюючи на основі бенчмаркінгу основний товарний асортимент ТОВ «Батьківщина» 3 товарами підприємства-лідера ТОВ «Агрофірма «Прогрес-Плюс», виявлено наступні результати (табл. 2.).

Таблиця 2

Бенчмаркінг основних видів продукції ТОВ «Батьківщина» в порівнянні 3 високорозвиненим підприсмством-лідером за 2018 р. *

\begin{tabular}{|c|c|c|c|}
\hline $\begin{array}{c}\text { Основний товарний } \\
\text { асортимент }\end{array}$ & ТОВ «Батьківщина» & $\begin{array}{l}\text { TOВ «Агрофірма } \\
\text { «Прогрес-Плюс» }\end{array}$ & $\begin{array}{c}\text { ТОВ «Батьківщина» до } \\
\text { лідера, \% }\end{array}$ \\
\hline \multicolumn{4}{|c|}{ Урожайність, ц/га } \\
\hline пшениця озима & 45,8 & 48,6 & 94,2 \\
\hline кукурудза на зерно & 48,2 & 54,2 & 88,9 \\
\hline ячмінь озимий & 42,9 & 47,1 & 91,1 \\
\hline соняшник & 29,5 & 36,2 & 81,5 \\
\hline \multicolumn{4}{|c|}{ Ціна реалізації продукції, грн./ц } \\
\hline пшениця озима & 377,8 & 408,0 & 92,0 \\
\hline кукурудза на зерно & 364,6 & 419,3 & 85,0 \\
\hline ячмінь озимий & 342,5 & 318,5 & 107,0 \\
\hline соняшник & 886,7 & 899,1 & 98,6 \\
\hline \multicolumn{4}{|c|}{ Собівартість реалізації продукції, грн./ц } \\
\hline пшениця озима & 277,4 & 251,4 & 110,3 \\
\hline кукурудза на зерно & 145,7 & 111,4 & 130,8 \\
\hline ячмінь озимий & 315,8 & 294,6 & 106,7 \\
\hline соняшник & 535,8 & 495,7 & 108,1 \\
\hline \multicolumn{4}{|c|}{ Рівень рентабельності, \% } \\
\hline пшениця озима & 36,2 & 62,3 & $-26,1 * *$ \\
\hline кукурудза на зерно & 150,2 & 276,4 & $-126,2 * *$ \\
\hline ячмінь озимий & 8,4 & 8,1 & $0,3 * *$ \\
\hline соняшник & 65,4 & 81,4 & $-16,0^{* *}$ \\
\hline
\end{tabular}

** відсоткові пункти

* сформовано авторами на основі даних фінансових звітів підприємств

Зростання конкурентоспроможності ТОВ Агрофірма «Прогрес-Плюс» супроводжується вищими рівнями ресурсовіддачі, прибутковості та рентабельності господарювання, вигідними реалізаційними цінами. Скорочення собівартості реалізованої продукції слід розглядати як беззаперечну конкурентну перевагу підприємства. Слід відмітити, що саме ефективне використання наявного ресурсного потенціалу є одним із основних факторів собівартості сільськогосподарської продукції.

Тоді як нижчий рівень урожайності основних сільськогосподарських культур ТОВ «Батьківщина» у порівнянні із підприємством-лідером свідчить про неефективне використання ресурсного потенціалу, застосування менш продуктивних сортів та менш ефективних технологій при їх виробництві, що й підтверджують показники рентабельності виробництва продукції.

Таким чином, можна виділити основні напрями підвищення конкурентоспроможності для сільськогосподарських підприємств, зокрема:

1) збільшення ефективності використання наявних ресурсів;
2) диверсифікація діяльності сільськогосподарських підприємств (виробництво органічної продукції та добрив, вирощування нетрадиційних сільськогосподарських культур, насінництво, біоенергетика, сільський туризм, аутсорсинг);

3) впровадження обгрунтованої системи мотивації персоналу, що сприятиме підвищенню ефективності та результативності праці;

4) оновлення матеріально-технічної бази на основі лізингового кредитування;

5) формування ефективної підприємницької стратегії на основі вдосконалення організації виробництва та впровадження концепції маркетингу;

6) поглиблення інтеграційних процесів і кооперування діяльності;

7) вдосконалення податкового механізму діяльності підприємств.

Зважаючи на високу залежність України від імпортних енергоносіїв, одним із стратегічних напрямків щодо оптимізації витрат на основі технологічної модернізації та ресурсозбереження $\epsilon$ використання біомаси (солома зернових культур та інші відходи рослинництва, гній, спеціально виро- 
щені енергетичні культури, агропромислові відходи) для виробництва палива. Особливо доцільним це є для підприємств, що займають нестійку конкурентну позицію.

Крім того, важливим також $є$ дотримання сільськогосподарськими підприємствами соціекономічних засад розвитку, що передбачає підвищення рівня екологізації виробничих процесів, вирішення економічних, соціальних та екологічних проблем сільської місцевості, соціальне забезпечення і підвищення кваліфікації персоналу, покращення якості життя сільської громади, використання принципів соціальної відповідальності у виробничогосподарській та ринковій діяльності [17, с. 397].

Висновки та перспективи подальших досліджень. Оцінка конкурентоспроможності підприємства - це визначення конкурентного становища підприємства на ринку та розробка обгрунтованих заходів щодо його покращення. Різноманітність методів ставить перед суб'єктом господарювання вибір оптимального методу оцінки конкурентоспроможності, який би не тільки констатував його поточний стан, а й дав змогу в сучасних ринкових умовах спланувати подальшу діяльність, вибрати найбільш вагомі фактори конкурентоспроможності та сформувати ефективну стратегію. Саме тому вважаємо доцільним використання системи методів для більш грунтовної оцінки конкурентоспроможності підприємства 3 врахуванням особливостей його діяльності та завдань, які потрібно вирішити.

Встановлено, що основними конкурентними перевагами для сільськогосподарських підприємств $\epsilon$ низька собівартість, що супроводжується відносною високою ресурсовіддачею та максимально повним використанням конкурентного потенціалу; вигідні реалізаційні ціни; висока ефективність діяльності. Крім того, одним із стратегічних орієнтирів формування конкурентоспроможності сільськогосподарських підприємств $є$ диверсифікація їх діяльності, яка стимулює інноваційний розвиток підприємства, сприяє підвищенню ефективності виробничо-господарської діяльності та забезпечує зменшення рівня ризиковості.

Подальші дослідження передбачають обгрунтування ефективних маркетингових стратегій забезпечення конкурентоспроможності аграрних підприємств на внутрішньому і зовнішньому ринках.

\section{Література}

1. Азоев Г.Л., Челенков А.П. Конкурентные преимущества фирмы. Москва: Новости, 2006. 267 с.

2. Портер М. Конкурентная стратегия: методика анализа отраслей и конкурентов / пер. с англ. И. Минервин. Москва: Альпина Бизнес Букс, 2005. 454 с.

3. Томпсон А., Стрикленд А. Стратегический менеджмент. Искусство разработки и реализации стратегии / пер. с англ. под. ред. Л. Г. Зайцева. Москва: Банки и биржи, ЮНИТИ, 1998. 576 с.

4. Фатхутдинов Р.А. Управление конкурентоспособностью организации. Москва: Эксмо, 2004. 544 с.

5. Шумпетер Й. Теория экономического развития. Капитализм, социализм и демократия / пер. с англ. В.С. Автономова. Москва: Эксмо, 2007. 861 с.

6. Амбросов В.Я., Маренич Т.Г. Оцінка конкурентоспроможності агроформувань // Вісник ХНАУ, серія «Економіка АПК і природокористування». 2009. С. 23-28.

7. Запша Г.М. Ефективність господарської діяльності аграрних підприємств в умовах трансформації відносин власності: регіональний аспект // Інноваційна економіка. 2013. №11. С. 127-133.

8. Збарський В.К., Місевич М.А. Конкурентоспроможність високотоварних сільськогосподарських підприємств. К.: ННЦАЕ, 2009. 310 с.

9. Малік М.Й., Нужна О.А. Конкурентоспроможність аграрних підприємств: методологія і механізми: монографія. К.: ННЦ IAЕ, 2007. 270 с.

10. Сахацький М.П., Запша Г.М., Белевят О.А. Наукові основи формування системи маркетингу в сільськогосподарських підприємствах // Економіка харчової промисловості. 2009. Вип. 1. С. 31-34.

11. Ульянченко О.В., Євчук Л.А., Гуторова І.В. Конкурентоспроможність сільськогосподарських підприсмств та стратегічні аспекти їі формування: монографія. Х.: Віровець А.П. «Апостроф», 2011.340 с.

12. Конкурентоспроможність підприємства: оцінка рівня та напрями підвищення / за заг. ред. О.Г. Янкового. Одеса: Атлант, 2013. 470 с.

13. Яців І.Б. Конкурентоспроможність сільськогосподарських підприємств. Львів: Український бестселер, 2013. 427 с.

14. Мельник C.I. Проблеми формування конкурентних переваг підприємств агропромислового комплексу в ринкових умовах: автореф. дис. ... докт. екон. наук: 08.00.04: захист 31.03.2011/ наук. кер. В.Г. Ткаченко. Луганськ, 2011. 32 с.

15. Забезпечення конкурентоспроможності аграрного сектора економіки України на внутрішньому і зовнішньому ринках: наукова доповідь / за ред. акад. УААН В. М. Трегобчука, чл.кор. УААН Б. Й. Пасхавера. К.: Інт екон. та прогнозув., 2007. 260 с.

16. Парсяк В., Дибач I. Аналітичні передумови управління конкурентоспроможностю невеликих підприємств // Економіст. 2010. №8. С. 56-59.

17. Найда I.C., Найда А.В. Методичні підходи щодо оцінки рівня соціоекономічного розвитку аграрних підприємств // Фінансово-кредитна діяльність проблеми теорії та практики. 2017. № 1(22). С. 396-405. doi: 10.18371/fcaptp.v1i22.93283 


\author{
Найда И.С. \\ кандидат экономических наук, ассистент \\ кафедра менеджмента \\ E-mail: irochka.lobankina@gmail.com \\ ORCID ID: 0000-0002-9706-7724
}

\begin{abstract}
Найда А.B.
кандидат экономических наук, доцент кафедра учета и налогообложения E-mail: andrew.od2017@gmail.com ORCID ID: 0000-0002-6371-1382
\end{abstract}

Галицкий А.H.

доктор экономических наук, доцент, кафедра экономической теории и экономики предприятия

Одесский государственный аграрный университет

ул. Пантелеймоновская, 13, м. Одеса, Украина, 65012

E-mail: oleksandrgalickij9@gmail.com

ORCID ID: 0000-0001-9549-7627

\section{СОВРЕМЕННЫЕ ИНСТРУМЕНТЫ ОЦЕНКИ КОНКУРЕНТОСПОСОБНОСТИ СЕЛЬСКОХОЗЯЙСТВЕННОГО ПРЕДПРИЯТИЯ}

Основной целью проведенного исследования является разработка и обоснование предложений по обеспечению высокого уровня конкурентоспособности сельскохозяйственных предприятий через использование современного инструментария его оценки. Объектом исследования избраны сельскохозяйственные предприятия Ширяевского района Одесской области, которые имеют общее географическое положение, соответственно подобные природно-климатические условия, организационно-правовую форму и специализируются на производстве зерновых и технических культур. Результаты научных исследований свидетельствуют об отсутствии единого подхода к оценке конкурентоспособности сельскохозяйственных предприятий. Обоснована необходимость использования различных методик для оценки уровня конкурентоспособности предприятий, что обеспечит получение наиболее фундаментальных результатов, даст возможность определить стратегическую позицию каждого предприятия, что является важным для разработки стратегических направлений.

Осуществлена оценка конкурентоспособности сельскохозяйственных предприятий с использованием современного инструментария (профиль конкурентоспособности, многоугольник конкурентоспособности, бенчмаркинг). С целью укрепления своих позиций на внутреннем рынке сельскохозяйственным предприятиям целесообразно уделять внимание таким составляющим конкурентоспособности, как уровню качества выпускаемой продукции и средним ценам на ее реализацию, совершенствованию организации инновационной деятельности, развития логистики и формированию эффективных стратегий маркетинга. Обоснованы направления повышения конкурентоспособности сельскохозяйственных предприятий, внедрение которых позволит увеличить объемы производства сельскохозяйственной продукции, укрепить экспортный потенциал, снизить затраты труда и средств, получить прибыли для обеспечения расширенного воспроизводства в сельском хозяйстве экономики в стране.

Ключевые слова: сельскохозяйственные предприятия, конкурентоспособность, оценка конкурентоспособности, конкурентные преимущества, конкурентный профиль, бенчмаркинг.

Naida I.

Ph.D., Assistant

Department of Management

E-mail: irochka.lobankina@gmail.com ORCID ID: 0000-0002-9706-7724
Naida A.

Ph.D., Associate Professor

Department of Accounting and Taxation

E-mail: andrew.od2017@gmail.com ORCID ID: 0000-0002-6371-1382

Halytskyi 0.

Doctor of Economics, Associate Professor

Department of Economic Theory and Economics of the Enterprise

Odessa State Agrarian University

Panteleimonovskaya str., 13, Odesa, Ukraine, 65012

E-mail: oleksandrgalickij9@gmail.com

ORCID ID: 0000-0001-9549-7627

\section{MODERN INSTRUMENTS OF COMPETITIVENESS ASSESSMENT OF AN AGRICULTURAL ENTERPRISE}

The main objective of the study is to develop and substantiate proposals to ensure a high level of competitiveness of agricultural enterprises through the use of modern tools for its evaluation. The object of research is the agricultural enterprises of the Shiryaevo district of Odessa region, which have a common 
geographical location and, accordingly, have similar natural and climatic conditions, organizational and legal form, and are specialized on the production of grain and technical crops. The results of the scientific research indicate that there is no single approach to the development of a system of indicators for assessing the level of competitiveness of the enterprise. The necessity of using different methods of assessing the enterprises competitiveness, which will provide the most thorough results, will enable to determine the strategic position of each enterprise, which is important for the strategic directions develpoment, has been substantiated.

The assessment of the competitiveness of agricultural enterprises using modern tools (competitiveness profile, polygon of competitiveness, benchmarking) has been conducted. In order to strengthen their positions in the domestic market, it is expedient for agricultural enterprises to pay attention to such components of competitiveness, as the quality of manufactured products and average prices for its implementation, the improvement of the organization of innovation activities, the development of logistics and the formation of effective marketing strategies. The directions of increase of the agricultural enterprises competitiveness, the introduction of which will allow to increase volumes of agricultural products production, to strengthen export potential, to reduce labor costs and funds, to receive profits to ensure expanded reproduction in agriculture economy of the country have been substantiated.

Key words: agricultural enterprises, competitiveness, competitiveness assessment, competitive advantages, competitive profile, benchmarking.

\section{References}

1. Azoev, G. L., \& Chelenkov, A. P. (2006). Konkurentnyie preimuschestva firmyi. Moscow: Novosti.

2. Porter, M. (2005). Konkurentnaya strategiya: Metodika analiza otrasley i konkurentov (I. Minervin, Trans.). Moscow: Alpina Biznes Buks.

3. Tompson, A., \& Striklend, A. (1998). Strategicheskiy menedzhment. Iskusstvo razrabotki i realizatsii strategii (L. G. Zaytsev, Trans.). Moscow: Banki i birzhi, YuNITI.

4. Fathutdinov, R. A. (2004). Upravlenie konkurentosposobnostyu organizatsii. Moscow: Eksmo.

5. Shumpeter, Y. (2007). Teoriya ekonomicheskogo razvitiya. Kapitalizm, sotsializm i demokratiya (V. S. Avtonomova, Trans.). Moscow: Eksmo.

6. Ambrosov, V. Ya., \& Marenych, T. H. (2009). Otsinka konkurentospromozhnosti ahroformuvan. Visnyk KhNAU, ekonomika APK i pryrodokorystuvannia, 23-28.

7. Zapsha, H. M. (2013). Efektyvnist hospodarskoi diialnosti ahrarnykh pidpryiemstv v umovakh transformatsii vidnosyn vlasnosti: Rehionalnyi aspekt. Innovatsiina Ekonomika, (11), 127-133.

8. Zbarskyi, V. K., \& Misevych, M. A. (2009). Konkurentospromozhnist vysokotovarnykh silskohospodarskykh pidpryiemstv. Kyiv: NNTsIAE.

9. Malik, M. Y., \& Nuzhna, O. A. (2007). Konkurentospromozhnist ahrarnykh pidpryiemstv: Metodolohiia i mekhanizmy. Kyiv: NNTs IAE.

10. Sakhatskyi, M. P., Zapsha, H. M., \& Beleviat, O. A. (2009). Naukovi osnovy formuvannia systemy marketynhu v silskohospodarskykh pidpryiemstvakh. Food Industry Economics, (1), 31-34.

11. Ulianchenko, O. V., Yevchuk, L. A., \& Hutorova, I. V. (2011). Konkurentospromozhnist silskohospodarskykh pidpryiemstv ta stratehichni aspekty yii formuvannia. Kh.: Virovets A.P. «Apostrof».

12. Yankovyi, O. H. (Ed.). (2013). Konkurentospromozhnist pidpryiemstva: Otsinka rivnia ta napriamy pidvyshchennia. Odesa: Atlant.

13. Yatsiv, I. B. (2013). Konkurentospromozhnist silskohospodarskykh pidpryiemstv. Lviv: Ukrainskyi bestseler.

14. Melnyk, S. I. (2011). Problemy formuvannia konkurentnykh perevah pidpryiemstv ahropromyslovoho kompleksu v rynkovykh umovakh (Doctoral dissertation) [Abstract]. 1-32. (UMI No. Dokt. ekon. nauk: 08.00.04)

15. Trehobchuk, V. M., \& Paskhaver, B. Y. (Eds.). (2007). Zabezpechennia konkurentospromozhnosti ahrarnoho sektora ekonomiky Ukrainy na vnutrishnomu i zovnishnomu rynkakh. Kyiv: Inst ekon. ta prohnozuv.

16. Parsiak, V., \& Dybach, I. (2010). Analitychni peredumovy upravlinnia konkurentospromozhnostiu nevelykykh pidpryiemstv. Ekonomist, (8), 56-59.

17. Naida, I. S., \& Naida, A. V. (2017). Metodychni pidkhody shchodo otsinky rivnia sotsioekonomichnoho rozvytku ahrarnykh pidpryiemstv. Finansovo-kredytna Diialnist Problemy Teorii Ta Praktyky, (1(22)), 396-405. doi: 10.18371/fcaptp.v1i22.93283

Received 15 April 2019

Approved 29 April 2019

Цитування згідно ДСТУ 8302:2015

Available in Internet 5.07.2019

Найда I.C., Найда А.В., Галицький О.М. Сучасні інструменти оцінки конкурентоспроможності сільськогосподарського підприємства // Економіка харчової промисловості. 2019. Т. 11, Вип. 2. С. 62-70. doi: 10.15673/fie.v11i2.1396

Cite as APA style citation

Naida I., Naida A. \& Halytskyi O. (2019). Modern instruments of competitiveness assessment of an agricultural enterprise. Food Industry Economics, 11(2), 62-70. doi: 10.15673/fie.v11i2.1396 